\title{
Flood Inundation Prediction of Logung River due to the Break of Logung Dam
}

\author{
Listyo Rini Ekaningtyas \\ Board of Financial Audit, Government of Indonesia, Jakarta, INDONESIA \\ listytyas@gmail.com
}

\begin{abstract}
The construction of Logung Dam in Kudus Regency is aimed to reduce the inundation area at downstream of Logung River, particularly during the rainy season. Besides, the potential water of Logung Dam is used for for irrigation and non-irrigation services. In order to mitigate the flood disaster that may arise in the downstream area, various preparedness should be established including the identification of flood hazard characteristics that may be caused by the break of the Logung Dam. This paper presents the results of Logung Dam break analysis using the levee pool routing model and the 2-D channel routing of the HEC-RAS 5.0 Version software. The initial value of breach parameter was calculated using the Froehlich's equation, and variation of breaking times $(1,2$, and 3 hours) were applied to study the generated hydrograph based on the corresponding elevation-storage curve. Furthermore, the simulation of channel routing at downstream of the dam was carried out in three different scenarios based on the bridges condition at downstream of the Logung Dam. Scenario 1 assumed that bridges will be safe enough against flood. Scenario 2 assumed that the bridges would only be safe at flood with return period lower than 20 years, whereas the scenario 3 assumed that bridges would be collapsed due to the flood at design flood with several return periods. The simulation results showed that the Probable Maximum Flood (PMF) with peak discharge of $1,303.60 \mathrm{~m}^{3} / \mathrm{s} \mathrm{did} \mathrm{not}$ generate overtopping. The peak discharge through the dam body was $15,022 \mathrm{~m}^{3} / \mathrm{s}$ at the first 40 minutes. It took 7 hours and 30 minutes to decrease the water level of the reservoir from $+95.2 \mathrm{~m}$ to $+38 \mathrm{~m}$. In scenario 2 , the simulation used 20 years return period flood with velocity in cross section before the Bridge RS 3700 was $7.21 \mathrm{~m} / \mathrm{s}$ and before Bridge RS 6800 was 5.72 m/s. Furthermore, the 2-D simulation results showed that at the near downstream of the Logung Dam, the maximum depth was 55 $\mathrm{m}$ and the maximum velocity was $39 \mathrm{~m} / \mathrm{s}$. Several prone areas to flood caused by the dam break are the villages at the left side of the downstream Logung River including Bulung Cangkring, Bulung Kulon, Sidomulyo, Pladen and Jekulo village.
\end{abstract}

Keywords: Logung Dam, dam break simulation, channel routing, flood prone area

\section{INTRODUCTION}

Dam is the hydraulic structure that stores the excess water during the rainy season and releases it in the dry season. Dams have several purposes such controlling flood due to the high inflow and providing both irrigation and non-irrigation water demands. Utilization of the dam can increase the welfare of the people at downstream area of the dam. However, dams may give disadvantages if the dams are not well operated and maintained. A big disaster such as flash flood may occur due to the break of the dams. Flash flood is a flood that occurs in a short period of time accompanied by a high discharge and usually conveys huge solid materials including sediment and trunks of tree. Dam break can be triggered by either overtopping or piping. Overtopping is the runoff water which flows through the top of the dam whilst erodes the dam body. Piping is the pipe erosions those take place through the dam embankment due to the poor quality of the dam embankment.

Logung Dam is located in the Slalang Sub-village, Tanjungrejo Village, Jekulo District, Kudus Regency, and Central Java Province. The purpose of the dam is to fulfill the water demand for irrigation, flood control and recreation (Ekaningtyas, 2017). The type of Logung Dam is rock fill type dam with straight core. The height of Logung Dam is $56 \mathrm{~m}$, with the crest elevation of $+95.2 \mathrm{~m}$, and the total storage is 20.15 MCM (million $\mathrm{m}^{3}$ ). Due to the dense population at the area near the downstream of Logung River, study on the inundation pattern due to possible break of the Logung Dam is considered important. The objectives of this research are to study the hydraulics performance of Logung Dam due to the high inflow, to determine the parameters of the break of the dam, such as the width, arrival time, and slope of the break, to carry out the dam break simulation at various parameter, and investigate the inundation pattern at the area near the downstream of Logung River. This study only analyzed the technical aspects, i.e. the hydrology and hydraulics aspects, while other aspects were not considered in the analysis. Lateral inflow due to the presence of the confluences and tributaries at downstream of the dams were neglected. 


\section{HISTORY AND IMPORTANT PARAMETERS}

\subsection{The World Worst Experiences}

Based on data of the causes of dam break over the world from 1900 until 1975, the dams which have more than 15 meters height experienced breaking or failure and mostly caused by overtopping followed by erosion of the dam crest (Salukh, 2004). Some of the breaks were caused by seepage that carried materials, piping, and other consequences due to earthquake occurrences (Table 1).

Table 1. Causes of the dam break in the world 1900-1975 (Salukh, 2004)

\begin{tabular}{llll}
\hline Cause & Concrete dam & Rock fill dam & Others \\
\hline Overtopping & $29 \%$ & $35 \%$ & $34 \%$ \\
Piping & $53 \%$ & $21 \%$ & $30 \%$ \\
Seepage & $0 \%$ & $6 \%$ & $8 \%$ \\
Others & $18 \%$ & $6 \%$ & $8 \%$ \\
Total & $100 \%$ & $100 \%$ & $100 \%$ \\
\hline
\end{tabular}

\subsection{Flood Hydrograph}

Flood hydrograph is the relationship between the flood discharges and duration of flooding time. It can determine the length of the occurrence, the arrival time of peak flow discharge and major flood peak discharge at any time. Flood hydrograph is generally used as a guideline in determining the duration time of the flood, water level in a certain location, as well as the time for evacuation and return to the location.

\subsection{Dam Break Simulation with HEC-RAS v.5.0}

The HEC-RAS system contains four hydraulic analysis components, i.e. steady flow water surface profile computations, one and two-dimensional unsteady flow simulations, movable boundary sediment transport computations, and water temperature and constituent transport modeling. All four components use geometric data and hydraulic computations routines (U.S. Army, 2016).

In addition to the four hydraulic analysis components, the system contains several hydraulic design features that can be invoked once the basic water surface profiles are computed. In the HEC-RAS software, there is a toolbar to model the flow triggered by the break of the dam. It can model the flow in accordance with the specified parameters of the dam break. Unsteady flow simulation is performed using HECRAS with dam break case, while the results are mapped using Arc GIS Software. Inundation of water resulted from dam failure model provides a preliminary assessment of flood risk and warning.

\subsubsection{Routing the Inflow Flood through a Reservoir}

There are two types routing the inflow flood through a reservoir that can be adopted by HEC - RAS software, namely level pool routing, and dynamic wave routing. Level pool routing method put the catchment area as upstream boundary condition in hydraulic modeling. The most important in this method is characteristic curve of reservoir between elevations of water level with volume of reservoir. The catchment area of reservoir must connect to upstream in the river. Instability in the running HEC-RAS can be reduced by minimum elevation of cross section in upstream river which must have the same elevation with that of reservoir (Brunner, 2014).

\subsubsection{Flood Routing in the Downstream Area}

After water inundates the downstream area, it turns to stop. The damping effect can be observed by the peak discharge measurements at each point in the river channel in the downstream. Change of the water flow is expressed by peak discharge reduction and arrival time, and changes of the hydrograph curve (Ndun, 2014).

\subsection{HEC-GeoRAS Software}

HEC-GeoRAS is one of the ArcGIS tools designated to process geospatial data. The results of the process can be used as data input geometry of HEC-RAS for hydraulics modeling. The river geometry cross-section can be made by using DTM data which has a good resolution. DTM data was then converted into a format TIN (Triangulated Irregular Network). In HEC-RAS 5.0.0 version, it can import topography data directly from the results of HEC-GeoRAS in the form of files (GIS2RAS.RAS Import) and can also put terrain converted TIN format from RAS-Mapper in 2D modeling.

\section{THEORETICAL CONSIDERATIONS}

\subsection{Rainfall Analysis}

Time concentration of rainfall can be obtained by analyzing a long record of short duration rainfall data. If the required data is not available, then the distribution of rainfall can be determined by the hypothetical model (Chow et al., 1988) such as uniform, triangle, bell shape, or Alternating Block Method (ABM), while the duration of the rainfall can be approached by some methods. One method that can be used to estimate the concentration time is Bransby-Williams equation.

$t_{c}=0.243 L A^{-0.1} S^{-0.2}$ 
where $t_{c}$ is time of concentration (hours), $A$ is area of watershed $\left(\mathrm{km}^{2}\right), L$ is length of main river $(\mathrm{km})$, and $S$ is slope of main river.

\subsection{Hydrology Analysis}

In hydrological analysis, methods of transformation are required for converting effective rainfall becomes runoff or surface runoff hydrograph (Sujono, 2014). The commonly used method is a unit hydrograph.Unit hydrograph can be obtained from the analysis of the pair of rainfall hyetograph dan flood hydrograph at a control point of watershed. It is called the observed unit hydrograph. If the rainfall data used for analyzing a unit hydrograph is not available, then it can be derived from the characteristics of the watershed, so called synthetic unit hydrograph (SUH). There are several SUH methods which are widely used in Indonesia, such as Nakayasu SUH developed in Japan, Gama I SUH developed by Prof. Sri Harto in Indonesia (Sri Harto, 2009), SCS SUH developed in the United States.

Gama I SUH consists of three main parts, namely the rising limb, crest, and recession limb. It comprises four variables of unit hydrograph, namely the rising time (TR), peak discharge $\left(Q_{p}\right)$, the base time (TB) and the recession time estimated by the value of the storage coefficient $(K)$. In Gama I SUH, the discharge of the recession time $\left(Q_{t}\right)$ is calculated using the following equation:

$Q_{t}=Q_{p} e^{-t / K}$

where $Q_{t}$ is discharge in $t$ hours $\left(\mathrm{m}^{3} / \mathrm{s}\right), Q_{p}$ is peak discharge $\left(\mathrm{m}^{3} / \mathrm{s}\right)$, and $K$ is coefficient of storage.

Nakayasu SUH is widely used in planning dams and several rivers in some places, for example in the Brantas River Project, East Java Province. Nakayasu SUH method is presented in the following equations:

$Q_{p}=\frac{1}{3.6}\left(\frac{A \times R e}{0.3 \times T p+T_{0.3}}\right)$

$T p=t_{g}+0.8 \times T r$

$t_{g}=0.4+0.058 \times L($ for $\mathrm{L}>15 \mathrm{~km})$

$t_{g}=0.21 \times L^{0.7}($ for $\mathrm{L} \leq 15 \mathrm{~km})$

$T_{0.3}=\alpha \times t_{g}$

$t_{r}=0.5 \times t_{g}$ where $Q_{p}$ is peak discharge $\left(\mathrm{m}^{3} / \mathrm{s}\right), A$ is area of watershed $\left(\mathrm{km}^{2}\right), R e$ is effective rainfall $(1 \mathrm{~mm}), T_{p}$ is time to peak (hours), $T_{0,3}$ is time from peak discharge until 0.3 times peak discharge (hours), $t_{g}$ is lag time (hours), $T_{r}$ is rainfall time unit (hours), $\alpha$ is characteristic coefficient, $L$ is length of main river $(\mathrm{km})$.

\subsection{Design of Flood}

Hydraulic design must be in accordance with the terms and specific rules depending on the magnitude of the hydrologic design (discharge or rainfall design). Design of the spillway should be able to pass the design flood up to the limit. If it is not capable of passing flood, the overtopping can cause dam break shortly. For a hydraulic structure that bears the high risk of damage and safety concerns, the determination of maximum flood discharge becomes very important.

\subsubsection{Probable Maximum Precipitation (PMP)}

PMP is used as input of rainfall-runoff analysis to determine the probable maximum flood (PMF). It expresses extreme rainfall occurred in certain duration time. Calculation of PMP needs quite a long-recorded rainfall data of a watershed. If the required data is not sufficient, an empirical hydrology modeling can be applied. Some consultants determine the amount of PMF by using PMP. PMP of hydraulic structure in Java is ranged between 650 and $850 \mathrm{~mm}$ (Sri Harto, 2009).

\subsubsection{Probable Maximum Flood (PMF)}

PMF analysis is intended to investigate the probability risk of dam break occurrence instantaneously. It can be estimated if the measured data of flow discharge is long enough, yet sometimes available data is not sufficient so PMP and PMF are analyzed by converting flow discharge from rainfall and the effluent unit hydrograph or using numerical simulation method (Linsley, 1982).

\subsection{Dam Break Simulation}

\subsubsection{Dam Break Mechanism}

The dam break process begins with failure that occurs in the body of the dam. The dam break mechanism is whenever the dam body breaks entirely, simultaneously and instantaneously. In the analysis of the flood inundation in the downstream area of the dam due to dam break, the dam break mechanism is assumed to occur completely and abruptly (Fread, 1980). Factors affecting the shape of the break include dam geometry, material constituent, dam construction, the type and slope of the break, the dimensions of the reservoir, and inflow discharge to the reservoir during 
the break of the dam, and the analysis methods (Froehlich, 2008). Overtopping occurs when cracks formed due to insufficiency of the reservoir to accommodate the amount of flow, thus exceeding the top of the dam. Damage caused by piping can be also simulated to determine the elevation of piping axis. The shape of fracture in piping is rectangular orifice which grows upwards or downwards in the dam body depends on the time. Instantaneous flow through the fracture is calculated by the flow formula through the orifice, depending on the position of the water level in the reservoir and the peak of the orifice.

\subsubsection{Estimating Break Parameters}

In order to simulate the dam break, the break size should be initially determined quantitatively (Fang, et al., 2016). The estimations of the break including location, size, and development time parameter are important to make an accurate estimate of the outflow hydrographs and downstream inundation. For estimating break parameters in HEC-RAS, there are two methods which can be applied, i.e. user centered data and simplified physical. The user centered data method requires all of the break information (break size, break location, break development time, break progression, etc). The simplified physical breaking methods require velocity versus break down-cutting and break widening relationships, which are then used dynamically to figure out the break progression versus the actual velocity being computed through the break, on a time step by time step basis. This research applied "User Centered Data" method. Parameters can be specified using regression approach generating from break occurrence data. Froehlich (2008) suggested some equations for obtaining parameters following the Break of the dam:

$$
\bar{B}=0.27 \times k_{o} V_{w}^{0.32} H_{b}{ }^{0.04}
$$

$$
t_{f}=63.2 \times \sqrt{\frac{V_{w}}{g H_{b}^{2}}}
$$

where $\bar{B}$ is average width break $(\mathrm{m}), t$ is break formation time (seconds), $V_{w}$ is reservoir volume when break $\left(\mathrm{m}^{3}\right), H_{b}$ is height of the fracture (m), $k_{0}$ is constant parameter (1.3 for overtopping and 1.0 for piping), and $g$ is acceleration due to gravity $(9.80 \mathrm{~m} / \mathrm{s})$

\subsection{Hydraulic Flood Routing}

Hydraulic flood routing is also called as dynamic wave dam. It was applied in this research since it was considered more accurate and can simulate waves of flooding due to dam break compared to search hydrology (Fread, 1980). Flood routing analysis based on unsteady flow equation is expressed by two free variables are water height $(h)$ and discharge $(Q)$ for each point along the channel. The continuity and momentum equations are necessary to solve those unknown variables.

Continuity equation:

$\frac{\partial A}{\partial t}+\frac{\partial Q}{d x}-q I=0$

Momentum equation:

$$
\frac{\partial Q}{\partial t}+\frac{\partial Q V}{\partial x}+g A\left(\frac{\partial z}{\partial x}+S f\right)=0
$$

where $Q$ is the flow rate $\left(\mathrm{m}^{3} / \mathrm{s}\right), A$ represents the look of the river $\left(\mathrm{m}^{2}\right), q I$ is discharge inflow lateral direction $\left(\mathrm{m} / \mathrm{s}^{2}\right), x$ is distance elongated the river $(\mathrm{m}), t$ is time (seconds), $v$ is flow velocity $(\mathrm{m} / \mathrm{s}), \frac{\partial z}{\partial x}$ the slope of water surface, $S f$ is the slope of the line energy defined as $S f=\frac{n^{2}|Q| Q}{A^{2} R^{2 / 3}}$ which $n$ is Manning roughness coefficient and $\mathrm{R}$ is hydraulics radius.

The Manning roughness, $n$ is quite difficult to determine because there is no certain way in the selection $n$ value. The widely used approach is by using tables of values $n$ Manning according to type of channels. Chow (1959) provided an empirical formula to estimate of the normal, minimum, and maximum values of $n$ Manning for different types of channels. The normal value iss suggested for channels that are well maintained only.

\section{RESEARCH METHOD}

\subsection{Description of Object of the Study}

Logung Dam which has an area of $43.81 \mathrm{~km}^{2}$ is located at downstream of the junction between Logung and Gajah River in Slalang Sub-village, Tanjungrejo Village, Jekulo Sub-district. Geographical location of the proposed dam is between $110^{\prime} 55^{\prime} 20.27 "$ BT and 06" 45' 28.38" LS. Inundation areas of the dam are Sintru Sub-village, Kandang Mas Village, Dawe Sub-district and Slalang Sub-village, Tanjungrejo Village, Jekulo Sub-district. All those areas are within the administrative area of Kudus Regency in Central Java Province.

\subsection{Data Collection}

This research used three rainfall stations, namely Gembong, Tanjungrejo and Rahtawu with the recorded daily rainfall data from 1970 until 2009. Secondary data describing watershed characteristics 
for calculating the SUH was obtained from the consultant company. The hydraulic data consists of the technical data of the dam, main dam design, dam characteristics describing correlation between storage volume and surface water elevation at dam (see Figure 1 ), and cross section of river in downstream of the dam (PT. Ika Adya Perkasa, 2014).

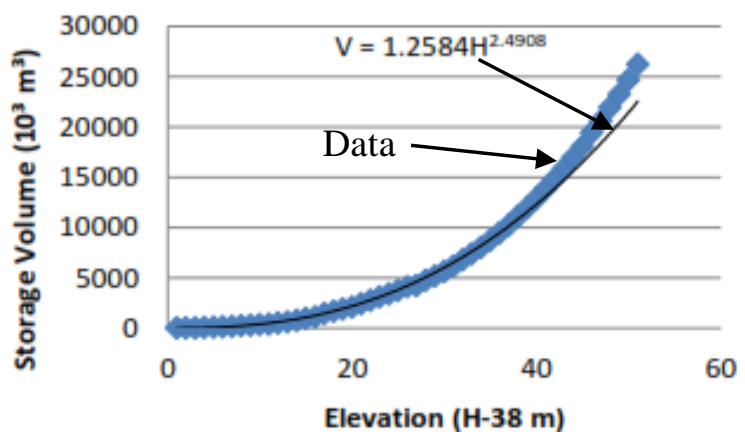

Figure 1. Correlation between water level and storage at reservoir (H-V Curve)

Cross section of the river was converted from topographical data gained from SRTM data and field measurements data. SRTM data used a resolution of 30x30 m downloaded from USGS website. The SRTM data apparently cannot accommodate the good geometry since width of river channel is around 30 $\mathrm{m}$. For complement the lack of data, SRTM data was combined with field investigation. The field measurements data was aimed to know the performance of the hydrodynamic model and the real condition around the research area. The field investigation was conducted on 15-16 June 2016.

\section{RESULT AND DISCUSSION}

\subsection{Hydrology Analysis}

The duration of the rainfall was determined by the equation of $t_{c}$ due to unavailability of hourly rainfall data. The results of tc then verified with a description of local residents. According to the information from local residents, the duration of rainfall usually lasts for 6 hours. Thus, rainfall duration of 6 hours is used in the calculation as shown in Table 2.

Table 2. Rainfall duration

\begin{tabular}{ll}
\hline Approach duration of rain (hours) & \\
\hline Kirpich & 2 \\
Bransby Williams & 6 \\
Australian Rainfall Runoff & 4 \\
\hline
\end{tabular}

PMP can be calculated by statistical analysis methods Harshfield, PMP values in Logung watershed is $509.1 \mathrm{~mm}$. The results of analysis Harshfield statistical methods are summarized in Table 3 .
Table 3. The Harshfield statistical methods of PMP

\begin{tabular}{ll}
\hline Parameter & Value \\
\hline$\overline{X_{n}}$ & 108.83 \\
$X_{n-m}$ & 104.38 \\
$X_{n-m} \sqrt{X_{n}}$ & 0.96 \\
$f_{1}$ & 1.01 \\
$f_{2}$ & 0.97 \\
$\overline{X_{p}}$ & 106.93 \\
$S_{n-m}$ & 30.16 \\
$S_{n-m} / S_{n}$ & 0.74 \\
$f_{3}$ & 1.07 \\
$f_{4}$ & 0.82 \\
$S_{p}$ & 35.91 \\
$K_{m}$ & 14.8 \\
PMP & 638.058 \\
\hline
\end{tabular}

The effective rainfall was calculated using SCS CN method which $\mathrm{CN}$ composite value. The value of $\mathrm{CN}$ composite is 71.40 as described in Table 4. The effective rainfall assumed in wet condition in which the value of $S$ and $I_{a}$ are 44.2 and 8.8, respectively.

Table 4. Calculation of $\mathrm{CN}$ composite

\begin{tabular}{lllll}
\hline $\begin{array}{l}\text { The type } \\
\text { of land use }\end{array}$ & $\begin{array}{l}\text { Area } \\
\left(\mathrm{km}^{2}\right)\end{array}$ & $\begin{array}{l}\text { Weight } \\
\text { of area }\end{array}$ & $\mathrm{CN}$ & $\begin{array}{l}\text { Weighted } \\
\mathrm{CN}\end{array}$ \\
\hline Thicket & 2.07 & 0.04 & 60 & 2.62 \\
Forest & 3.72 & 0.08 & 58 & 4.56 \\
Housing & 5.27 & 0.11 & 74 & 8.23 \\
Grass & 0.00 & 0.00 & 73 & 0.00 \\
$\begin{array}{l}\text { Irrigation } \\
\text { Rice field }\end{array}$ & 1.78 & 0.04 & 68 & 2.56 \\
$\begin{array}{l}\text { Rainfall } \\
\text { Rice field }\end{array}$ & 15.09 & 0.32 & 75 & 23.91 \\
Moor & 19.53 & 0.41 & 72 & 29.53 \\
$\Sigma$ & 47.33 & 1 & $\mathrm{CN}_{\text {composite }}$ & 71.40 \\
\hline
\end{tabular}

The hourly rainfall distribution was calculated by ABM method for several return periods including PMP. The maximum daily rainfall was calculated using frequency analysis shown in Table 5 . Comparison between Gama I and Nakayasu SUH is shown in Figure 2.

Table 5. Precipitation at various return period

\begin{tabular}{ll}
\hline Precipitation $\left(\mathrm{P}_{\mathrm{T}(\text { years })}\right)$ & $\mathrm{mm}$ \\
\hline $\mathrm{P}_{2}$ & 98.7 \\
$\mathrm{P}_{5}$ & 131.8 \\
$\mathrm{P}_{10}$ & 157.6 \\
$\mathrm{P}_{25}$ & 185.3 \\
$\mathrm{P}_{50}$ & 226.3 \\
$\mathrm{P}_{100}$ & 261.2 \\
$\mathrm{P}_{1000}$ & 409.2 \\
$\mathrm{PMP}$ & 638.06 \\
\hline
\end{tabular}




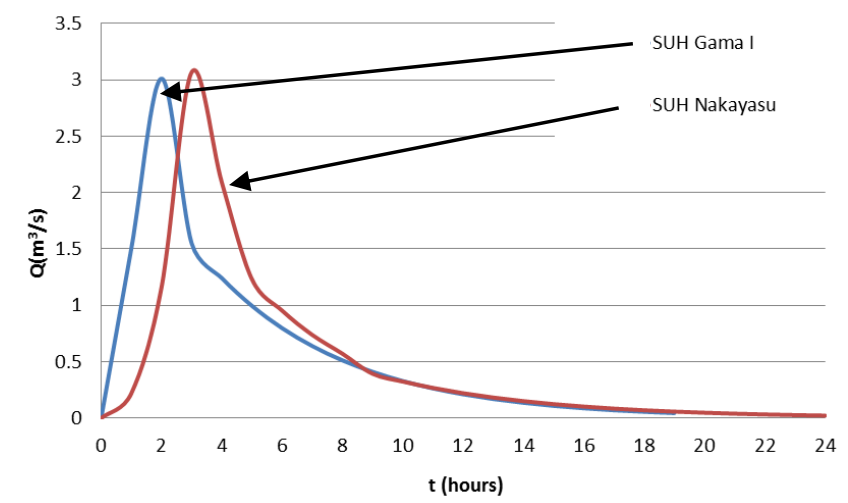

Figure 2. Synthetic Unit Hydrograph (SUH)

\subsection{Flood Hydrograph}

In this study, the dam break simulation applied the PMF flood hydrograph. For the case of GAMA I SUH, the obtained peak discharge was $1276.35 \mathrm{~m}^{3} / \mathrm{s}$ with peak time of 4 hours, while from Nakayasu SUH, the obtained peak discharge was $1303.6 \mathrm{~m}^{3} / \mathrm{s}$ with peak time of 5 hours. The results of PMF Flood Hydrograph used Gama I and Nakayasu were shown in Figure 3.

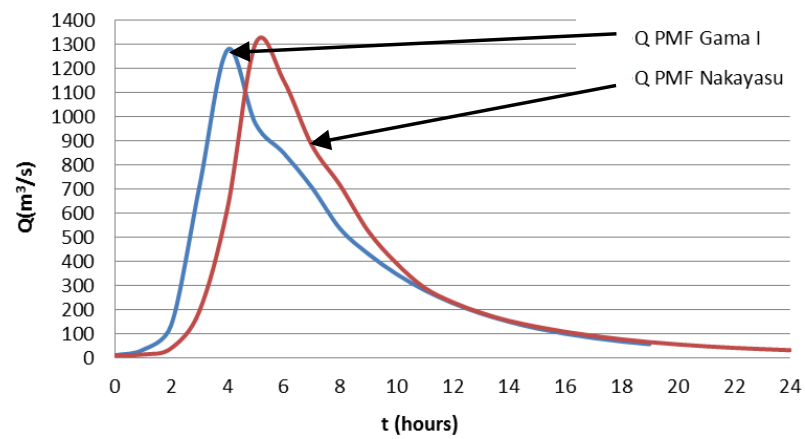

Figure 3. PMF flood hydrographs

\subsection{Reservoir Routing Analysis}

The commonly used method for reservoir routing analysis is by applying the equation of mass conservation. The reservoir storage characteristic, i.e. the relationship between volume, elevation and area, together with the spillway geometry and a certain inflow hydrograph were then used in the routing process. The result of the routing presents the hydrograph of inflow, out flow and reservoir water elevation at one particular condition. The analysis of reservoir routing using the PMF was carried out to know whether or not the dam experience overtopping (reservoir water level exceeds $+95.20 \mathrm{~m}$ ). When the Gama I SUH PMF was applied, the peak discharge of outflow was $1,123.28 \mathrm{~m}^{3} / \mathrm{s}$ and the maximum height of over flow above the spillway was $4.71 \mathrm{~m}$. For the case of the Nakayasu SUH PMF, the peak discharge of outflow was $1,226.30 \mathrm{~m}^{3} / \mathrm{s}$ with the maximum overflow height above the spillway was $5.06 \mathrm{~m}$ (see Figure 4).

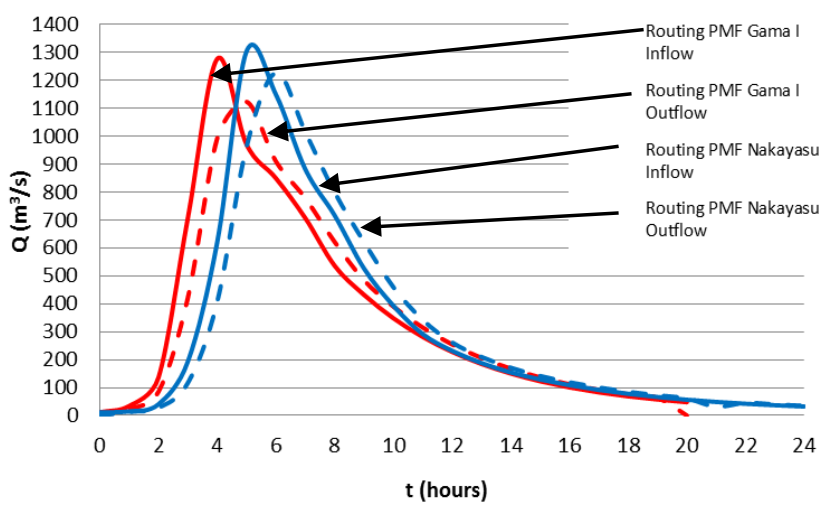

Figure 4. Inflow outflow hydrographs of reservoir routing

\subsection{Hydraulic Analysis}

HEC- RAS Software 5.0.0 version was used to simulate the model scenario and to integrate onedimensional analysis for channel flow model and twodimensional analysis for modeling the inundation area caused by dam break. Dam break analysis was divided into two models namely one-dimensional model with storage area (reservoir) using piping model and analysis section of downstream along the $11.8 \mathrm{~km}$ by using two-dimensional model.

\subsection{Dam Break Analysis}

The dam break analysis was carried out using the storage area (see Figure 5) and one-dimensional model (levee pool routing model). In order to avoid the complexity of the analysis, the dam break analysis only used the piping mechanism, neglecting the overtopping mechanism. The analysis was carried out to obtain the outflow hydrograph after a certain break formation time. For the study of dam break analysis, three break formations time were used, i.e. the 1 hour, 2 hours, and 3 hours. The results of the calculation of the break parameters are shown Table 6. The purpose is to determine the relationship between outflow discharge and the break time formation.

Table 6. Parameters of Dam Break

\begin{tabular}{ll}
\hline Parameter of Dam Break & Magnitudes \\
\hline Break formation time $(t f)$ (hours) & 1 \\
& 2 \\
& 3 \\
& 80 \\
Average width break $\left(B_{\text {ave }}\right)(\mathrm{m})$ & 0.7 \\
Slope of break $(\mathrm{H} / \mathrm{V})$ & 42 \\
Bottom break width (m) & 141.87 \\
Up break width (m) & +38 \\
Bottom break elevation $(\mathrm{m})$ & +95.2 \\
Up break elevation $(\mathrm{m})$ & \\
\hline
\end{tabular}




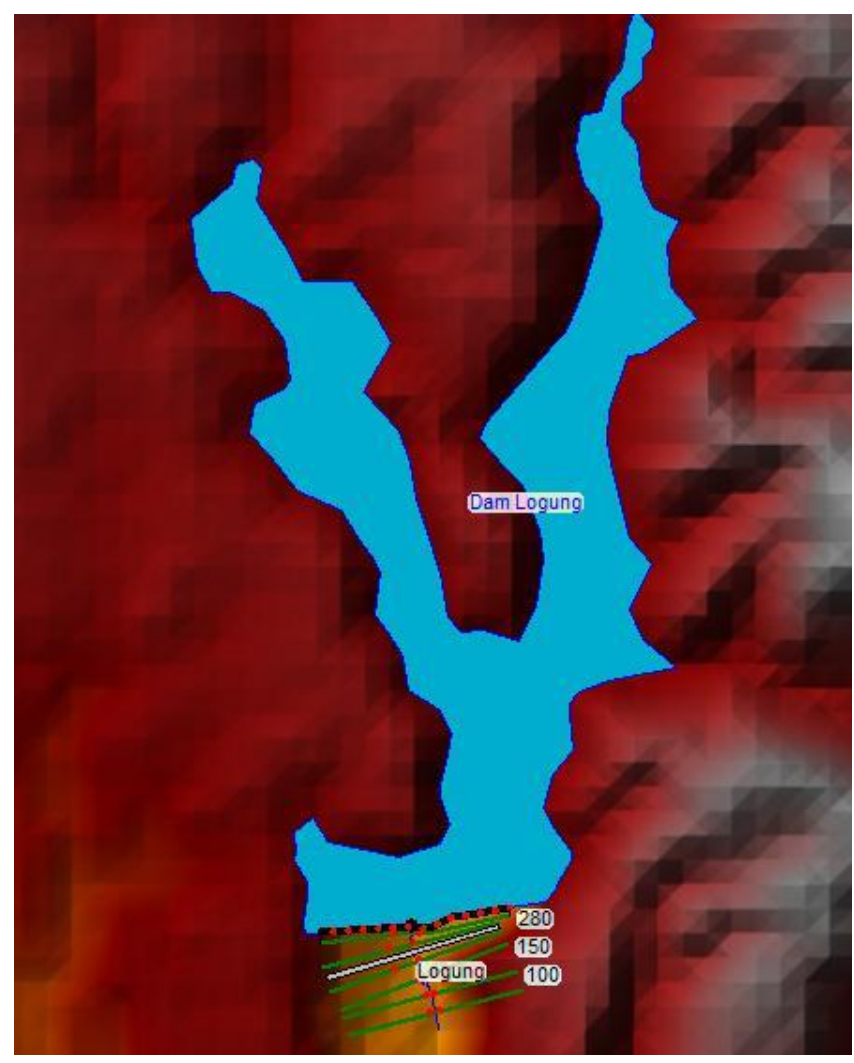

Figure 5. Storage area of Logung Dam

\subsection{Outflow Hydrographs}

The HEC RAS has two different methods for modeling the dam break by using levee pool routing method. The first method is by using the correlation between the elevation and volume of the reservoir storage or H-V curve, whereas the other method is by using the storage volume data (depth multiplied by the area). In this study, both of the methods were used and the higher value was taken for the next analysis. The break formation time affects the resulted outflow hydrograph. The longer of the break formation time, the lower resulted outflow hydrograph (see Figure 6).

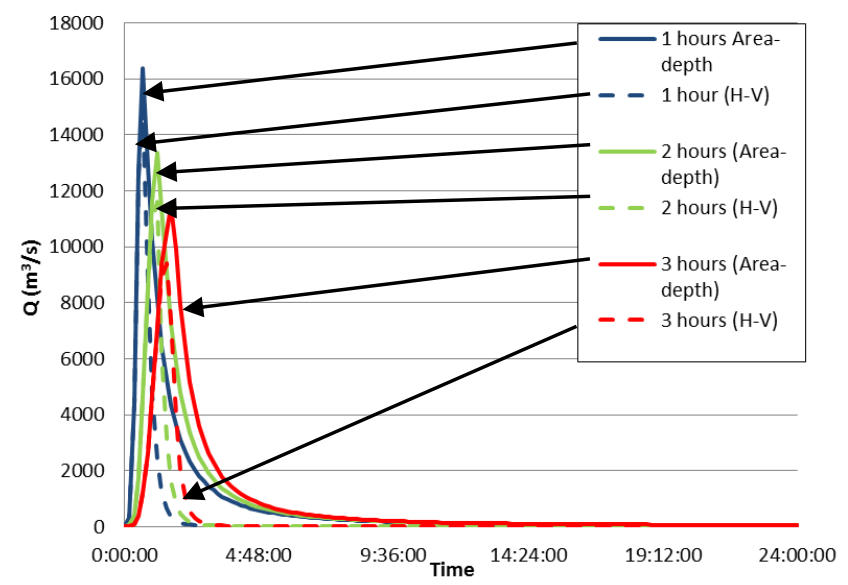

Figure 6. Outflow hydrographs after dam break

\subsection{Inundation at Downstream Area}

The two-dimensional model was used to study the inundation pattern as caused by the dam break. Throughout the entire study, the area being modeled was the area near the downstream Logung River, i.e. approximately $11.8 \mathrm{~km}$ downstream of the Logung Dam. There are three bridges and one weir modified bridge along the downstream Logung River. The inundation area studied included Kudus Regency and a few parts of Pati Regency. The simulations were carried out in three different scenarios namely Scenario 1, Scenario 2 and Scenario 3. Simulation of Scenario 1 was carried out using the outflow hydrograph produced by the dam break at original geometry and its bridge structures along the Logung River. Simulation of Scenario 2 was carried out using the 20 years return period of outflow hydrograph resulted from the reservoir routing of the Logung Dam, whereas Scenario 3 was carried out using outflow hydrograph resulted from the dam break, and using the river geometry without any bridge.

\subsubsection{Scenario 1 Simulation}

The increase of flow velocity caused by the dam break may give impact to the stability of the river crosssections including the bridge structures. There are two possibilities that may happen due to the flow occurrence, the bridges would remain stand or otherwise would collapse due to the hydrodynamic of the flow. It was assumed however, that during the entire process of simulation, no river geometry is assumed to be unchanged and the bridges remained stand. In this simulation, the maximum outflow hydrograph $\mathrm{Q}$ was $15,022 \mathrm{~m}^{3} / \mathrm{s}$ (from tf 1 hour $\mathrm{H}-\mathrm{V}$ ) Curve method. The result of simulation in the form of maximum water level along the Logung River was presented in Figure 7.

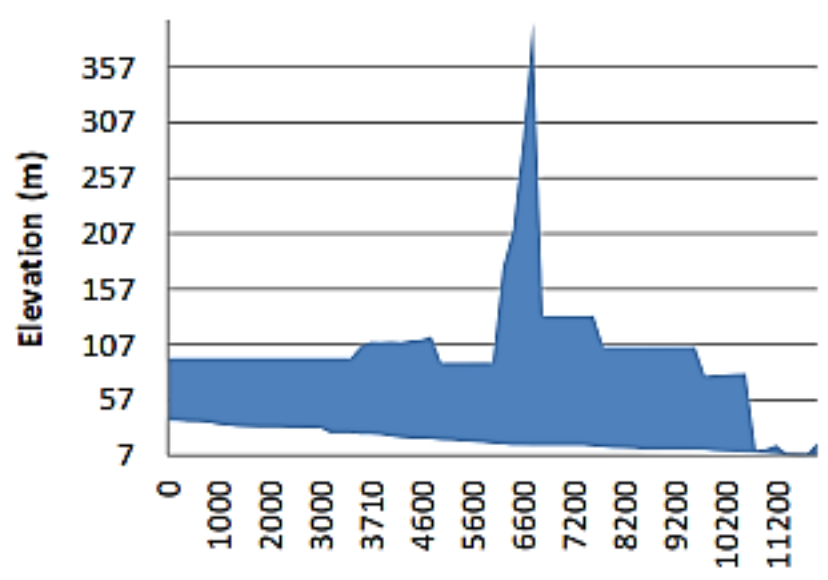

Figure 7. Maximum water level along Logung River at Scenario 1. 


\subsubsection{Scenario 2 Simulation}

Figure 7 showed that Scenario 1 has very high water level at reach RS 6800. The purpose of Scenario 2 was to convince that the bridge may or may not collapse due to the flow as caused by 20 years return period of outflow hydrograph from Logung Dam. According to Scenario 2 simulation, it was found that the flow velocity at some locations were higher than 5 $\mathrm{m} / \mathrm{s}$, i.e. $5,75 \mathrm{~m} / \mathrm{s}$ and $7.00 \mathrm{~m} / \mathrm{s}$ at RS 3700 and RS 6800 respectively. The summary of the flow velocity at for different return period of flood hydrographs are shown in Table 7. The maximum water level and the maximum flow velocity along the Logung River are presented in Figure 8 and Figure 9, respectively.

Table 7. Summary of velocity from each of the return periods

\begin{tabular}{llll}
\hline \multirow{2}{*}{$\begin{array}{l}\text { Flood Hydrograph } \\
\left(\mathrm{Q}_{\mathrm{T}(\text { year })}\right)\end{array}$} & \multicolumn{3}{l}{ Velocity (m/s) } \\
\cline { 2 - 4 } & RS 3700 & RS 6800 & RS 11600 \\
\hline $\mathrm{Q}_{2}$ & 2.29 & 2.57 & 0.68 \\
$\mathrm{Q}_{5}$ & 2.79 & 3.23 & 1.05 \\
$\mathrm{Q}_{10}$ & 4.83 & 3.87 & 2.01 \\
$\mathrm{Q}_{20}$ & 7.21 & 7.21 & 2.61 \\
\hline
\end{tabular}

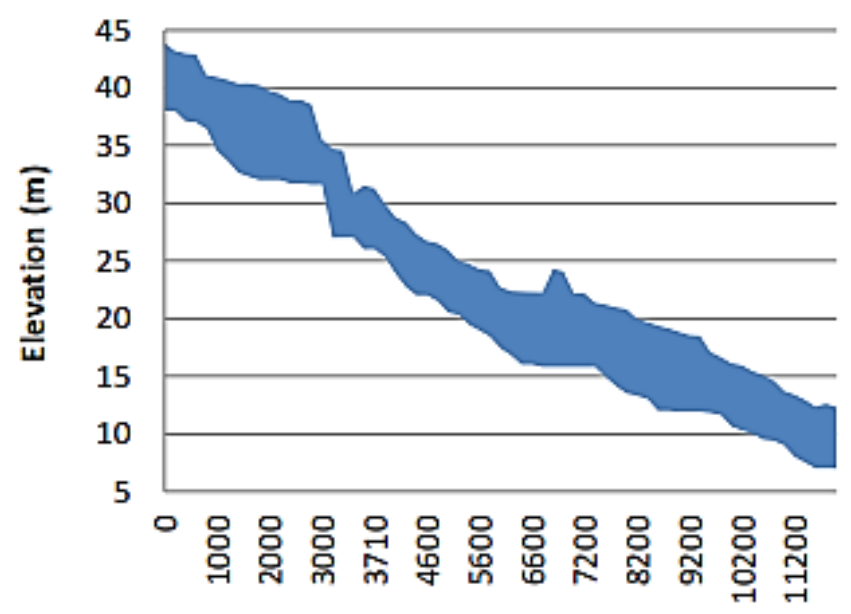

Figure 8. Maximum water surface profile



Figure 9. Maximum velocity profile
It is seen from Figure 8 that the maximum water level at reach RS 6800 has nearly reached $+25.00 \mathrm{~m}$, with the maximum velocity (see Figure 9) was around 4.00 $\mathrm{m} / \mathrm{s}$. Another situation shows that at reach RS 5600, the maximum water level was also nearly $+25.00 \mathrm{~m}$ whereas the maximum velocity was $5.75 \mathrm{~m} / \mathrm{s}$. These two illustrations show that the reach RS 6800 is less prone than that of reach RS 5600 .

\subsubsection{Scenario 3 (river without inline structure)}

In this scenario, the bridges were assumed to have been destroyed by the high flow before the flow has reached its peak hydrograph. The simulation used the maximum outflow hydrograph as it was used in the Simulation 1 . The geometry of the Logung River used in the simulation was the geometry without any bridge structure. The maximum water level along the Logung River that was resulted from Scenario 3 simulation was shown in Figure 10.



Figure 10. Profile water surface maximum $t f$ (1 hour)

Further analysis of the results obtained from Scenario 3 simulation was then processed spatially by applying the RAS Mapper and the Arc Map. The results of the aforesaid process in the form of flood inundation map and flood velocity map are presented in Appendix 1 and Appendix 2 respectively. The affected areas as caused by the dam break are mostly located on the left side of the river which has a lower elevation such as Bulung Cangkring village, Bulung Kulon village, Sidomulyo village, Pladen village and Jekulo village. Furthermore, the affected village that was located on the right side of the river were only partially affected such as Kirig village, Temulus village, Kesambi village, Jojo village, Sadang village, Hadiwarno village, and Hadipolo village. 


\section{CONCLUSIONS AND RECOMMENDATIONS}

\subsection{Conclusions}

Some conclusions those may be withdrawn from the study are as follows:

a) The dam break simulation results conclude that the maximum discharge were approximately 15,022 $\mathrm{m}^{3} / \mathrm{s}, 13,200 \mathrm{~m}^{3} / \mathrm{s}$ and $11,500 \mathrm{~m}^{3} / \mathrm{s}$ for 1 hour, 2 hours and 3 hours break formation time respectively.

b) The dam break simulation that used the $\mathrm{H}-\mathrm{V}$ curved method and the 1 hour break formation time yielded the $15,022 \mathrm{~m}^{3} / \mathrm{s}$ peak discharge, and caused decrease of reservoir water level from $+95.00 \mathrm{~m}$ to $+39.98 \mathrm{~m}$ in 7 hours and 30 minutes.

c) The channel routing simulation of Logung River using 20 years return period of outflow hydrograph from the Logung Dam resulted flow velocity of $4.00 \mathrm{~m} / \mathrm{s}$ and $5.75 \mathrm{~m} / \mathrm{s}$ at reach RS 6800 and RS 5600 respectively.

d) The two-dimensional simulation of scenario 3 contributed the maximum depth of flow of $55 \mathrm{~m}$ and maximum velocity of $39 \mathrm{~m} / \mathrm{s}$, both were located at the Logung River reach close to the dam. The major affected areas caused by the dam break are located on the left side of the river. The flood prone areas are at Bulung Cangkring, Bulung Kulon, Sidomulyo, Pladen and Jekulo village.

\subsection{Recommendations}

The followings are some recommendations for further flood mitigation efforts:

a) The Dam break simulation caused by overtopping should be physically modeled although the mathematic model calculation used PMF flood hydrograph has been done.

b) During the process of simulation, the geometry of the Logung River should be made possible to accommodate their changes due to the instability of the structures.

c) Further study on the application of the simulation results to prepare flood velocity map and flood inundation map is essential for developing the emergency action plan of the Logung Dam break disaster.

\section{REFERENCES}

Brunner, G., 2014. Using HEC-RAS for Dam Break Studies, Davis: USACE, Institute for Water Resources, Hydrologic Engineering Center.

Chow, et al, 1988. Handbook of Applied Hydrology, Singapore: McGraw Handbook.
Chow, V. T., 1959. Open Channel Hydraulics, New York: Mc Grow Hill Book Company.

Ekaningtyas, L. R., 2017. Flood Inundation as Caused by Dam Break of Logung Dam, Kudus Regency, Central Java Province, Yogyakarta: Master Thesis, Faculty of Engineering, Universitas Gadjah Mada.

Fang, C. H., Chen, J. \& Xiao, K., 2016. A New Method to Quantify Breach Sizes for the Flood Risk Management of Concrete Arch Dams. Journal of Flood Risk Management. DOI:10.1111/jfr3.12240

Fread, D., 1980. DAMBRK: The NWS dam-break flood forecasting model, Silver Spring: National Weather Service, Office of Hydrology.

Froehlich, D., 2008. Embankment Dam Breach Parameters and Their Uncertainties. Journal of Hydraulic Engineering, American Society of Civil Engineers, Volume 134, pp. 1708-1721.

Linsley, R., 1982. Hidrologi Untuk Insinyur [Hydrology for Engineer]. 3 ed. Jakarta: Erlangga.

Ndun, J., 2004. Simulasi 1-D Banjir Akibat Keruntuhan Bendungan dengan Program HEC-RAS 4.1.0 Studi Kasus Embung Tambakboyo, Kabupaten Sleman, Provinsi DIY, Yogyakarta: Master Thesis, Faculty of Engineering, Universitas Gadjah Mada.

PT. Ika Adya Perkasa, 2014. Laporan Analisa Hidrologi Sertifikasi Desain Bendungan Logung di Kabupaten Kudus [Analysis of Hydrology for Certification Design of Logung Dam, Kudus Regency]. PT. Ika Adya Perkasa.

Salukh, F. I., 2004. Analisis Penelusuran Banjir Akibat Keruntuhan Bendungan [Analysis of Flood Routing due to Dam Break], Yogyakarta: Master Thesis, Faculty of Engineering, Universitas Gadjah Mada.

Sri Harto, B., 2009. Hidrologi Teori, Masalah, dan Penyelesaian [Hydrology: Theory, Problem, and Solving]. Yogyakarta: Nafiri Offset.

Sujono, J., 2014. Petunjuk Singkat Aplikasi HECHMS [Short Guideline of HEC HMS Application], Yogyakarta: Lecture's Note, Department of Civil and Environmental Engineering, Universitas Gadjah Mada.

U.S. Army, 2016. HEC-RAS River Analysis System, User's Manual, Version 5.0. U.S. Corps of Engineers. 


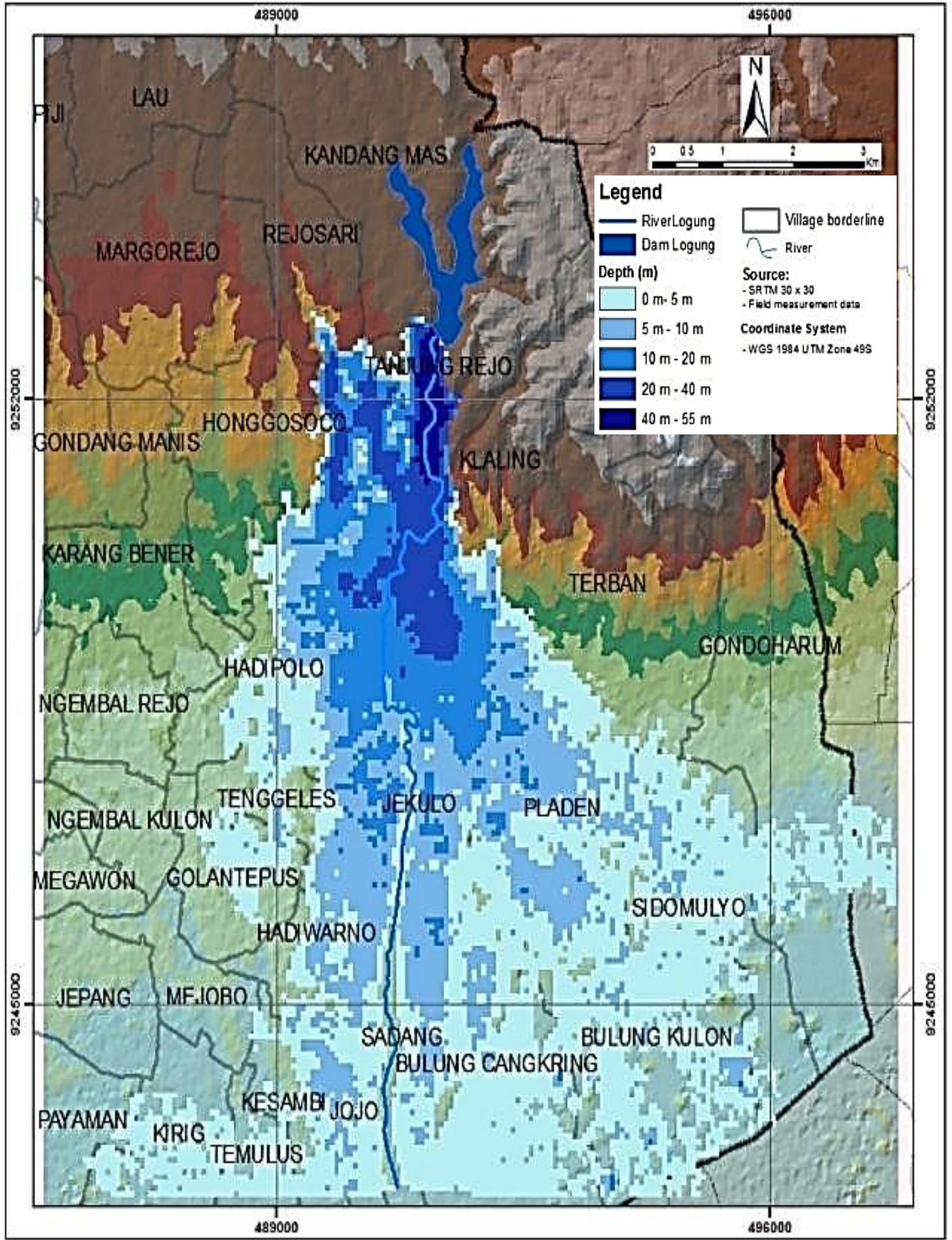

Appendix 1. Flood inundation map 


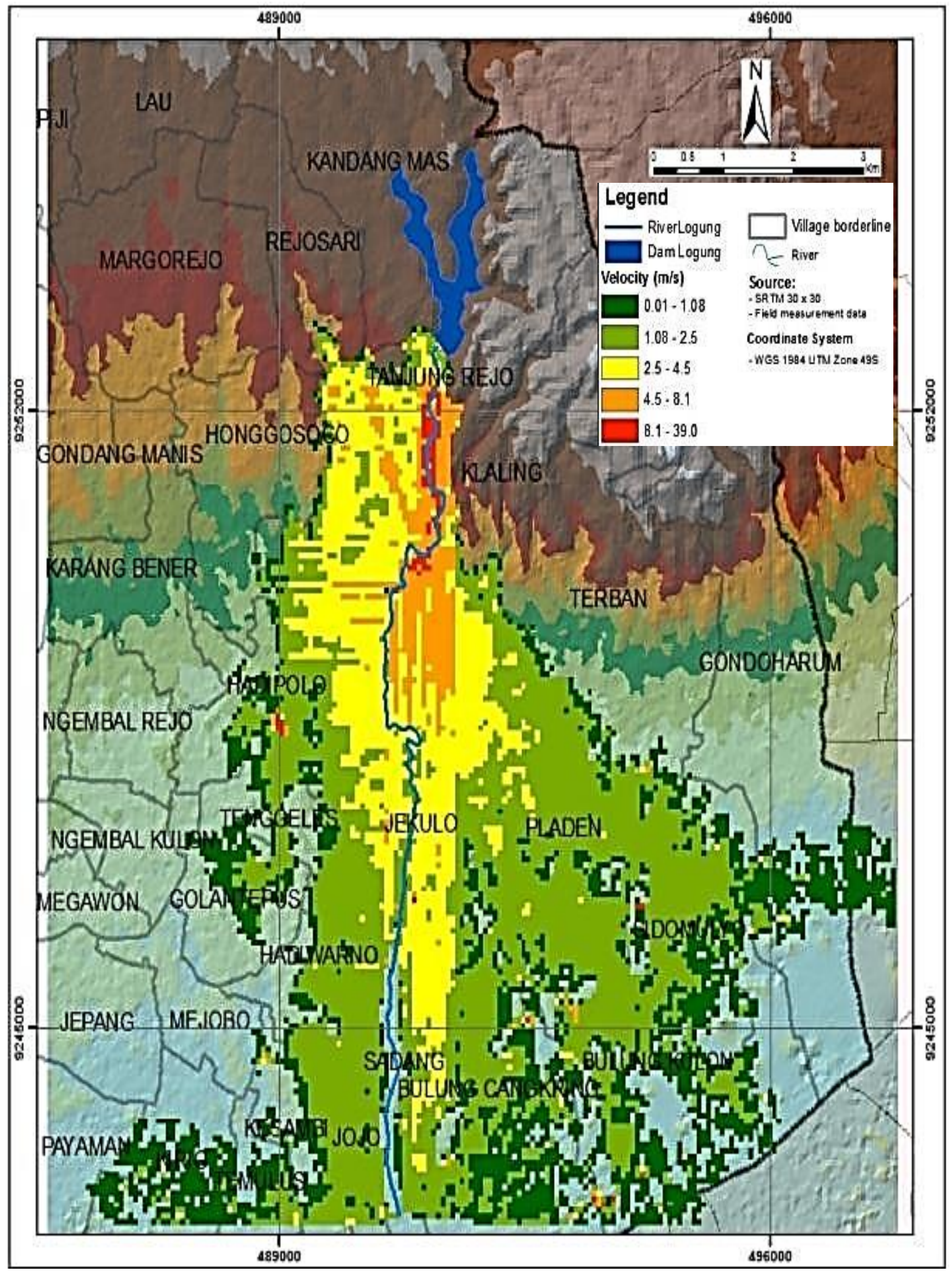

Appendix 2. Flood velocity map 
[this page intentionally left blank] 